Historic, Archive Document

Do not assume content reflects current scientific knowledge, policies, or practices. 

62.79

f

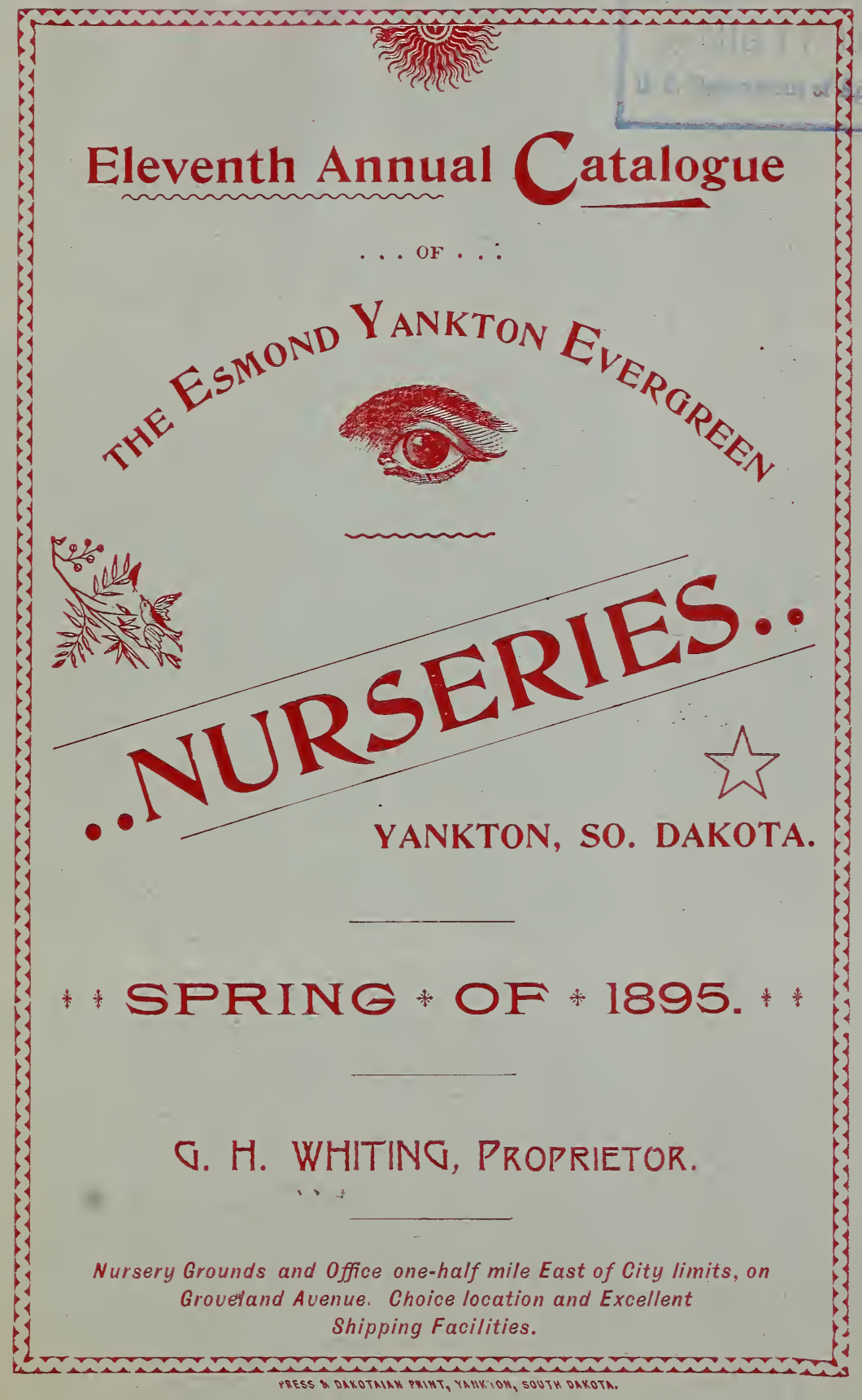




\section{SPRAY PUMPS.}

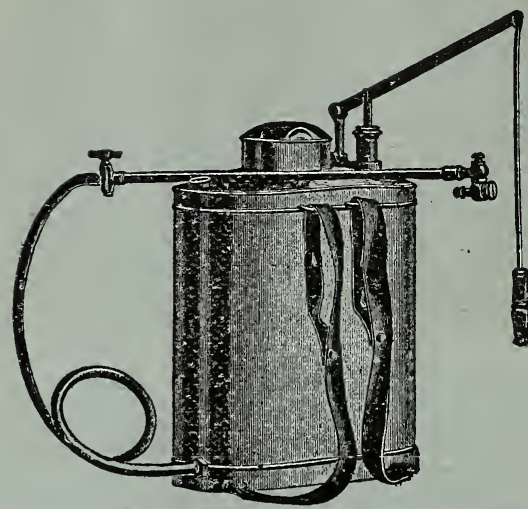

KNAPSACK SPRAYING OUT. FIT - This machine consists of a copper reservoir holding about five gallons. The pumps being made entirely of brass and copper can neither rust nur corrode. There is a large air chamber inside of the reservoir which will keep up the pressure, and continue to discharge the spray for nearly one minute after the operaror stops pumping. A brass pipe fifteen inches in length, with a stopcork, is furnished with each machine, including the celebrated Vermoral Nozzie. Price Complete, \$1l.jo.

Barrel Spraying Outfit-For use on barrel; furnished with eight feet of discharge hose, "Excelsior Nozzle" and three feet of return hose to keep liquid well mixed in the barrel. Price Complete without Barrel, $\$ 10.00$.

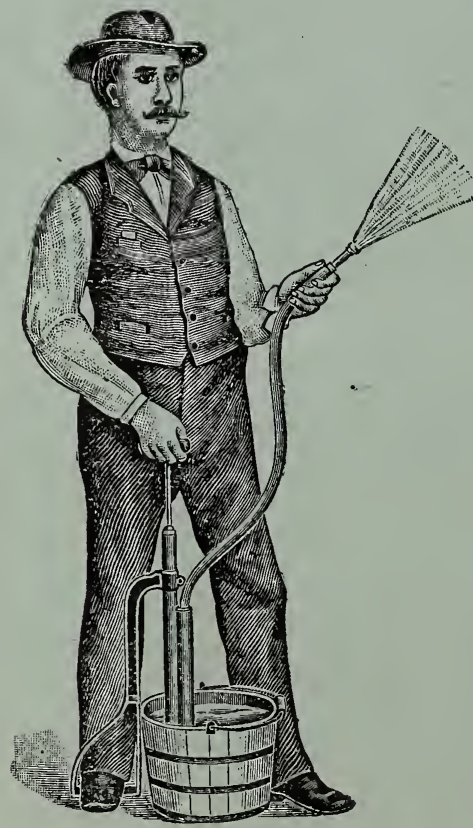

Excelsior Spraying Outfit.

For a good, cheap outfit. this is unquestionably the best on the market. The cylinder, and in fact all the working parts are brass, being thus constructed of materials that will resist the acrion of fungicides. Two nozzles are furnished with this outfit, one being used for spraying purposes and the other for washing windows, buggies, etc., For spraying it is arranged so it discharges a fine jet at bottom of the bucket to kfep the solution thoroughly mixed. It is provided with a large air chamber so that the nozzle throws a constant. continuous, even, spray all the timf. Price Complete, $\$ \mathbf{4 . 5 0}$. Full directions for spraying the different varieties of vegetables and fruits will be sent with each outfit sold. 


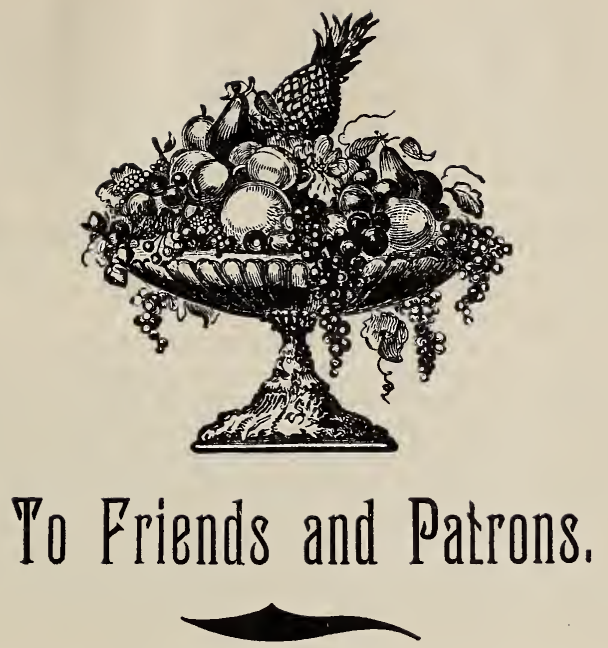

¿F $N$ presenting this, my Eleventh Annual Catalogue, I desire H to thank all old customers for their liberal patronage, and I hope by good assortment of stock, careful handling and square dealing, to be deserving of the same in the future; and also to add many new names to my rapidly increasing list of customers. It shall always be my aim to deal with my patrons in such a way that they will have no occasion to complain, and will come again.

\section{LOCATION AND STOCK.}

It gives me pleasure to be able to say that my present location is among the very best in the Northwest, enabling me to ship direct over the "C. M. \& St. P." the "C. \& N. W." and the "Great Northern" Railways, and by Ex. via. the "Am." the "U. S." and the "Great Northern" Express Co's.

My facilities for growing Stock are unsurpassed. With my place under a first class system of artesian irrigation I am able to offer my customers thrifty, vigorous and well grown Stock. There is no question but that better stock can be grown in this way than by depending on the natural rainfall, as the growth can be secured at the proper season and time given for the complete ripening of the wood: Accompanying cuts show the comparative growths of irrigated and non-irrigated trees

Our Motto, "Good Stock, True to Name and Carefully Handled." 
The following is a clipping from "The National Nurseryman" of Dec. 1894, of Rochester, N. Y.: "We prefer to plant young stock that it may receive an early start in life and by ilrigation we force the growth as our judgment dictates. We believe trees grown by irrigation are best grown and that a tree well planted is half made." Here you have in a nut-shell, some valuable hints and they come from the east too, where it would seem that irrigation was unnecessary.

I shall endeavor as in the past, to grade all stock so that it will be well up to the standard in quality, discarding all worthless and inferior trees or :plants, and strive always to please my customers.

My list of varieties, although not large, is comprised almost wholly of valuable and hardy sorts. I shall strive always to keep in stock such varieties as will be of value to my customers, believing that their success is mine as well.

All stock which proves untrue to label. will be replaced free of clisrge, but it is mutually agreed that we will not be responsible for damages further than the price paid for the stock. Mistakes will sometimes occur in spite of our best efforts. When out of the variety ordered, we sometimes substitute other similar varieties, unless forbidden, but will follow instructions as closely as possible at all-times. Order early.

$\rightarrow$ PACKING.

The packing season begins with us in the spring ahout April lst. Fully realizing how utterly worthless good stock may be made by careless and improper packing; how days, and even years, of labur may be thrown away by a few moments of neglect, in handling, all stock will be carefully and securely packed in good strong boxes, barrels or bales (using plenty of wet moss or litter to keep roots moist, ) and delivered at freight, express or post office without extra charge. After such delivery my responsibility ceases.

All claims for losses caused by delays or otherwise, while en route, should be made at once on the carriers. Any errors which may occur in filling orders will be cheerfully corrected, if notified within ten days after receipt of goods; otherwise no claims will be allowed.

\section{TRANSPORTATION RATES.}

Very small packages go as cheap by express and are less liable to delays. No package will be taken by freight for less than 25 cents.

All goods by freight shipped released to a value of $\$ 5.00$ per 100 pounds (umless otherwise ordered) which secures the special low tree tariff.

If the stock is ordered sent by mail, add one cent for each two ounces for postage. 


\section{站. \\ Direct Deal with the Planter.

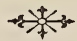

I wish to state that I have adopted the plan of dealing direct with my customer's without the employment of expensive, and often unreliable,agents, who merely work for personal gain, caring little or nothing for the in terests of their customers or the Nursery they represent. By this method I secure a better class of customer's who buy only what they want and can take care of.

I feel confident that by dealing with you direct I can give you more and better goods for the same money, than by the agent system; and if anything is wrong, or not as represented you know at once, where to attach the blame, and can get a prompt adjustment of your claim.

If you think you have reason for complaint, please inform me at once of your grievances, and I will endeavor, if possible, to adjust them satisfactorily. This is much better and more manly than to circulate it among your neighbors, which would rarely, if ever, do you any good, and would do me an injury and perhaps a grave injustice.

\section{$\rightarrow$ PRICES.}

'This list abrogates all previous quotations, My prices, I think, will compare favorably with any reliable Nursery in the northwest. Please bear in mind that when you get trees or plants for less than they can be grown and properly handled, they are almost invariably deficient in some respect. The old saying that "the best is the cheapest," applies to nothing more forcibly than to Nursery'stokk.

$$
\rightarrow \text { TERMS. }
$$

My terms are net cash before delivery of stock. I will in no case ship stock until I have satisfactory proof that the pay is forthcoming. Your standing may be the best, but. I have no time in the delivery season to ascertain, and cannot take chances.

It is no more trouble for purchasers to remit with the order than to wait a few days, They will in every case get just as good a deal, and orders will be filled more promptly. No

Buy your Trees, Direct from the Grower and Save Money. 
stock will be reserved or sent C. O. D., unless one-third cash accompanies the order. Remittances may be made by registered letter, express or bank draft. Do not send private check. Prices in this list are for quantities specified. To those who have never favored me with an order I would say please give me a trial order and let me prove to you that my prices are very low, quality considered. I have a better stock, both in quality and variety, than ever before.

GEO. H. WHITING,

Yankton, S. D.

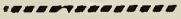 \\ Hints on Handling and Planting.}

6] 9 92 them your attention at once; wet thoroughly and then place them in moist earth at once. It is best not to unpack or let the air to the roots until you are readv to care for them.

In this way, by taking a few precautions, purchaser can have stock almost or quite as fresh as when it left the Nursery.

ORCHARDS.-While the higher elevations and northerly slopes have a percentage of advantrges in favor of commercial orcharding, the family orchard should be near the house. Would plant a heavy wind-break on south, and light on north side; a heavy south wind-break checks the force and lessens the ardity of the southerly winds. Do not plant the wind-breaks within fitty feet of the orchard. For wiud-breaks, Soft Maple, Box Elder, Ash, Evergreens, etc., will be found most suitable. I would plant Apple and Crab trees 16 to 20 feet apart; Cherry trees 12 to 16 feet; and Plums abont 8 to 12 feet.

Have the ground well plowed and pulverized before planting and set the trees solid; leave a little loose dirt on the surface. Then either keep the surface perfectly mellow by cultivation or mulch four inches deep and eight feet from tree all around. I prefer thorough cultivation to mulch as it has a tendency to encourage deeper rooting

In trimming (especially apple trees) in this severe climate always avoid as much as possible cutting large limbs, in fact use the KNIFE as little as possible and keep the tree in proper shape. as severe wounds tend to produce llackheart and decay. thereby maling the tree short lived. The better way to keep your trees in the proper shape is to watch them closely in the growing :eason, removing all unnecessary buds and pinching back those that are liable to make too much growth. 


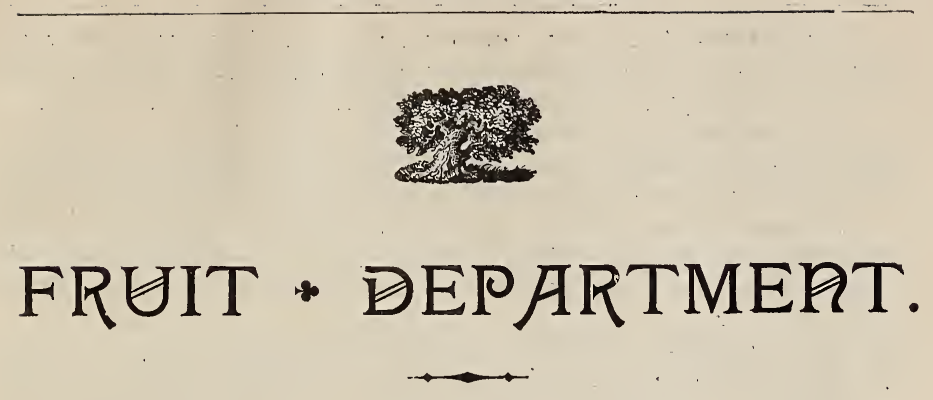

SUMMER APPLES.

Duchess of O.-Large size, productive and very hardy, quite showy, very tart and a good cooker. Season, September.

Yellow Transparent-Of Russian origin, very hardy and produc_ tive; color, when ripe, pale yellow; size medium; slightly sub-acid;shape roundish oblate; ripens in Sept.

\section{FALL APPLES.}

Haas-A vigorous grower; fruit medium to large, shaded and striped with red; tender, juicy, sub-acid. Oct. to Nov.

Wealthy-A seedling originated in Minn., very bardy, an abundant and early bearer ; fruit large, dark crimson, flesh crisp, sub-acid, white tinged with red, good quality. Nov. to Feb.

Perry Russet-Tree a good grower and hardy, fruit good size and quality, sub-acid, color yellow. Nov. to Feb.

\section{WINTER APPLES.}

McMahons White-Originated in Wis., fruit very large, nearly white, a good cooker, very hardy and productive. Nov, to Jan.

Wolf River-Extremely hardy, fruit of the largest size and very handsome, skin a greenish yellow shaded with crimson, flesh white, juicy, tender, with pleasant sub-acid flavor. Tree a strong grower and great bearer. Dec. to Feb.

Pewaukee-A seedling from. Duchess, fruit medium to large, surface yellow, partially covered with dark red, flesh yellowish whit , juicy, sub-acid with a rich aromatic flavor. A strong grower and vesy hardy. Dec. to March.

Ben Davis - A tree highly esteemed in the west, fruit conical y shaped, large, striped and of fair quality, juicy, sub-acid, very productiv quite hardy here. Dec. to Mar. 
Longfield-A Russian variety; a free upright grower, early and abundant bearer, fruit medium to large, yellowish green thickly covered with red stripes, rich, sprightly, sub-acid; hardy here. Dec. to Feb.

Northwestern Greening-Tree of Wis., origin. A vigorous grower and very hardy, fruit large, of greenish yellow color, sometimes tinted with red, sub-acid, quality excellent. March to June.

salome-Tree medium grower and quite hardy, fruit medium roundish, conical, pale yellow splashed with red and sprinkled with small yellow dots; flesh tender, juicy, mild sub-acid; first class. Jan. to June.

Walbridge-A vigorous upright grower, quite hardy here; fruit medium size striped with red, good quality. March to June.

Mann-An upright grower, forming a round head; fruit medium to large,roundish oblate, skin deep yellow with a shade of brownish red where exposed, flesh yellowish, juicy, mild sub-acid; very good. April to June.

Price's Sweet-A good grower and quite hardy here, fruit medium size good quality; an excellent keeper.

\section{HYBRID APPLES--(Hardy anywhere.)}

Sylvan Sweet-'Tree slender but vigorous upright grower, fruit large, pale yellow with rich blush, flesh white, tender and very good. August.

Transcendent--A well known strong and vigorous grower, bears very abundantly, fruit of excellent quality for culinary use; its only fault is a tendency to blight. Sept.

Whitney's No. 20--Tree fine, straight, upright grower, fruit large size, conical, red and yellow striped, flesh crisp, sub-acid, quality excellent for eating. Sept.

Martha-A seedling from Duchess, it rapid,stiff grower, pyramidal, great bearer, fruit very beautiful, medium size, glossy, yellow, shaded with bright red, mild tart; excellent. Oct. and Nov.

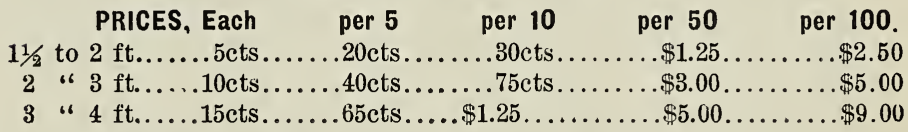

NOTICE-.-Of the following varieties, I have none in stock larger than 2 to $3 \mathrm{ft}$. viz.: Yellow, Transparent, Perry Russett, McMahons White, Longfield, N. W. Greening, Salome and Price's Sweet. Please bear this in mind when making up your orders. Also remember that young trees make the best and longest lived orchards.

Remember the Agent is an Expensive Concern. Buy Direct. 


\section{PLUMS.}

Forest Garden-Hardy, bears profusely, fruit one to one and a half inches in diameter,oblong, color mottled red and yellow; skin thin, juicy, rich and sweet. Ripens in Aug.

Wolf---Fruit very large, a perfect free-stone, quality excellent for cooking or eating from hand. Ripens late in Aug.

De Soto-Extremely hardy, a very abundant annual bearer, fruit good size, meat sweet, firm and juicy, color red and yellow; ripens about Sept. 1st.

Wild Seedlıngs--Some of them will bear_quite well a fruit of fair quality, but they are not very reliable.

\section{PRICES, Each per 5 per 10 per 50 per 100}

F. Garden; Wolf 3 to $5 \mathrm{ft} \ldots . .30 \mathrm{cts} \ldots . . \$ 1.25 \ldots \$ 2.25 \ldots . \$ 10.00 \ldots \$ 18.00$

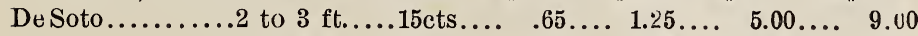

" $\ldots \ldots \ldots \ldots . .3$ to 5 ft.....30cts.... $1.25 \ldots .2 .25 \ldots 10.00 \ldots . .18 .00$

$\begin{array}{llllll}\text { Wild } \ldots \ldots \ldots \ldots \ldots .2 \text { to } 3 \mathrm{ft} \ldots \ldots 10 \mathrm{cts} \ldots . . & .40 \ldots . & .75 \ldots . & 5.00 \ldots & 5.00\end{array}$

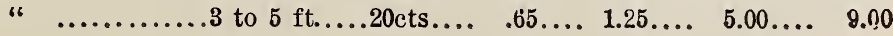

\section{CHERRIES.}

Early Richmond---An early red acid cherry, very valuable for cooking, tree a free grower, hardy, healthy and very productive. Kipens in June.

Wragg-It is a sturdy grower, very hardy and an immense bea rer, fruit large, dark colored and handsome. Ripens in July.

Am. Morello-Tree extremely hardy and a good grower; quite productive, fruit fair size and quality; rich acid flavor.

Sand Cherry - A native of divarfish habits, perfectly hardy anywhere in the Dakotas, fruit about the size of Ea. Richmond, color dark brown to black, somewhat astringent to eat from hand but cooks well, a very early and abundant bearer; can be planted about as close as currants; very desirable in the northwest. Ripens in July and Aug.

PRICES, Each per 5 per 10 per $\mathbf{5 0}$ per 100

Ea. Rich., Wragg 3 to 4 ft. ...30cts...\$1.25 ...\$2.50 ...\$12.00...

Am. Morello..... 3 to 5 ft....30cts... 1.25... 2.25 ... 10.09...

Sand Cherry..... 1 to $2 \mathrm{ft} . \ldots .15 \mathrm{cts} \ldots . .65 \ldots 1,00 \ldots .4 .00 \ldots \$ 7.00$

" $"$. $\ldots .2$ to $3 \mathrm{ft} . \ldots 25 \mathrm{cts} \ldots .1 .00 \ldots 1.75 \ldots 7.50 \ldots 14.00$

Trees Poorly Packed are often Worse than Worthless; We Pack Securely. 
Buffalo Berry-A native shrub or tree sometimes growing to a beight of $15 \mathrm{ft}$ or more, perfectly hardy anywhere, bears abundantly if properly fertilized, should be planted in groups containing both pistilates and staminates. fruit about the size and color of Red Dutch currant, quite tart and juicy, makes a delicious jelly, a very ornamental shrub.

\begin{tabular}{|c|c|c|c|c|}
\hline PRICES, Each & per 5 & per 10 & per 50 & per 100 \\
\hline to $2 \mathrm{ft} \ldots \ldots \ldots \ldots . . .10 \mathrm{c}$ & & ....75c... &..$\$ 3.00 \ldots$ & $\ldots \$ 5.00$ \\
\hline to $3 \mathrm{ft} \ldots \ldots \ldots \ldots . . . . .20 \mathrm{c}$ & $\ldots . .7 \check{c}$ & $\$ 125 \ldots$ &. $.5 .00 \ldots$ & ... 9.00 \\
\hline
\end{tabular}

\section{GRAPES.}

Plant in rows 12 feet apart and 8 feet apart in row on good well drained soil, cultivate clean and the second spring after planting set posts 5 fept high 24 feet a part in the rows On these stretch three smooth fence wiles 18 inches apart. Select two of the strongest canes and cut to a length of four feet (remove all other canes) and tie these loosely one each way on the lower wire allowing the shoots to run up to the other wires. In the fall cut these laterals back 2 or 3 buds and continue this year after year increasing length of main canes a little each year. Renew canes orce every 4 or 5 years. Prune in fall and lay dnwn and cover with course litter; keep suckers pincher off during summer.

Agawam-(Rogers No.15) Vigorous grower; bunch good size, berries large and round; color rather dark red, skin thin with jiucy pulp very sweet and rich, season ten days earlier than Concord.

Concord---A vigorous hardy vine, berries large and black,skin thin, flesh juicy and sweet, ripens early in September, the leadiug market variety.

Clinton-Bunches medium size, compact, shouldered, berries small; acid vinous flavor, color black, ripens early. Its extreme hardiness makes it desirahle here.

Moore's Early-A very early black grape, bunch large, berry round, very hardy and productive, the quality is better and it ripens 20 days ahead of the Concord.

Wilder-(Rogers No. 4) Black, bunch and berry large, of excellent quality and a good keeper, vine a moderate grower, hardy and productive but liable to over bear, ripens with the Concord.

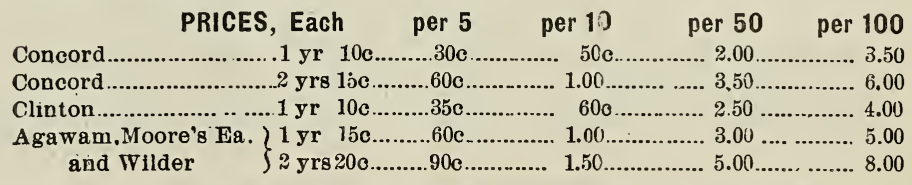




\section{CURRANTS.}

Plow deep and have the soil well pulverized before planting. We plant rows 8 feet apart and 4 feet apart in row; give good clean culture and manure well. Cut out old wond occasionally and keep the bush vigorous and healthy. The varieties listed here are all perfectly hardy, enduring well our coldest winters and dryest summers.

Red Dutch--A hardy, well known, standard variety, early.

Victoria--Large, red, late; seems very well adapted to South Dakota; has produced excellent crops with me annually.

White Grape--So far has proven the best bearer I have fruited here, bearing a full crop annually of large bunches and large-sized fruit;

Cherry - The largest of the red currants, dark red and rather acid. strong grower, and very productive.

Black Naples---A very rank, strong grower, and very productive fruit, large, black, and of a musky flavor, adheres well to the bush; excellent for cooking.

Crandall---A seedling of the Mo. River wild currant, which it resembles very much but it is claimed to be much larger and much more prolific. I have not had it long enough to know much about it.

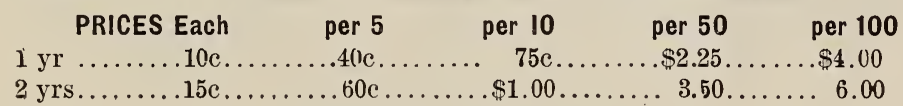

\section{GOOSEBERRIES.}

Give same treatment and care as previously instructed for currants.

Houghton-A medium sized, American variety, bears abundant and regular crops and never mildews; fruit smooth, red, tender and very good, hardy nearly every where.

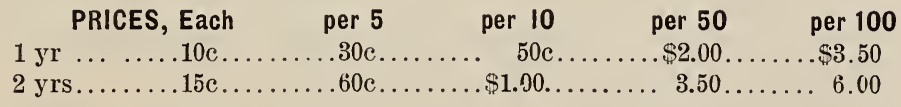

\section{RASPBERRIES.}

Plant in rows 8 feet apart and 3 feet apart in row; give clean culture, keep down all suckers and weeds. Lay down and cover in fall; this corering may not always be necessary to prevent winter killing but they will produce enough more fruit to pay abundantly.

Please give Explicit Shipping Directions, Otherwise we use our best Judgmenţ. 
Turner-Red, vigorous grower, early, fruit of excellent quality, a good bearer, very hardy.

Onio--Hardy and claimed to be the greatest producer among the blackcaps, medium size and fine flavor.

Tyler--Blackcap, truit of good qualityand very productive, hardy.

Gregg--The largest of the blackcaps, good quality, not quite so hardy as others named, should have winter protection.

$\begin{array}{ccccc}\text { PRICE, per } 10 & \text { per } 50 & \text { per } 100 & \text { per } 500 & \text { per } 1000 \\ 25 c \ldots \ldots & \ldots & 90 & \ldots & \$ 1.50 \ldots \ldots\end{array}$

\section{BLACKBERRIES.}

Stones Hardy-One of the lowest growing blackberries, very hardy and productive.

Lucretia Dowberry--The dewberry is, I think, destined to take the place of the blackberry in this locality, as its trailling habits adinit of its being easily protected with either airt or mulch during winter. The Lucretia is very large, early and enormously productive.

PRICES, per $10 \quad$ per $\mathbf{5 0}$ per $\mathbf{1 0 0}$ per $\mathbf{5 0 0}$

Stones Hardy......40c......\$1.25........\$2.00

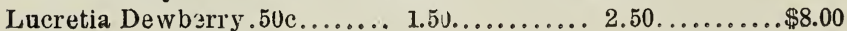

\section{STRA WBERRIES.}

Plant in spring in rows four feet apart and one foot in row. In planting, great care should be taken too get roots well spread out and well down iu the ground, but dou't plant so deep that the crown of the plant will be cuvered with dirt by the rain; if you do they will rot and die. Mulch late in fall with hay or csia-stalks, to avoid foul seed which are so numerous in straw.

Staminate varieties bear by themselves, but pistilates require a staminate variety every third or fourth row to make them productive. Please bear this in mind, when making your selectiuns. l'lant at least two rows of pistilates to oue of staminates, as they are more productive.

Crescent-(Pistilate,) Une of the most productive sorts, good quality and large; succeeds well almost anywhere if properly fertilized.

Warfield No. 2-(Pistilate,) Plant a vigorous grower; endures drouth well, blossoms and ripens with the Crescent; it is very productive good size and a good shipper.

Mt. Vernon-(Staminate,) Productive, late, it is a large, well shaped, smooth berry of good quality.

Chas. Downıng-(Stamivate, ) Good size, fine flavor, very productive; a strong and vigorous plant. Season medium.

See Cut on Page 12, Showing Roots of my Irrigated Seedlings. 
Plants will betrimmed of deяd leares, etc, and neatly tide iu bunches of 25 each; we caunot break bunches.

PRICE, Per $25,40 c ; 100, \$ 1.00 ; 500, \$ 4.00 ; 1000, \$ 7.00$

\section{MISCELLANEOUS.}

Mammoth Rhubarb-This is a very large sort; early tender and fine flavored.

ROOTS; Each 15c; 5, 60c; 10,\$1.00; 50, \$4. $0 ; 100, \$ 7.00$

Asparagus; Uonovors C.-This is a well known and valuable garden and market sort; every fumily should have a bed of Asparagus.

STRONG ROOTS; Per 10, 25c; 50, 75c; 100, \$1.25; 500, \$4.00

HORSE RADISH SETS; per $10,40 \mathrm{c} ; 5 ?, \$ 1.00 ; 100, \$ 1.5 \mathrm{~J}$

\section{PLANTS.}

Tomato and Cabbage Plants-These plants will be good, strong, early started plants, either early or late; sorts as desired.

TOMATO PLANTS; per $10,20 \mathrm{c} ; \ldots \ldots . .50,75 \mathrm{c} ; \ldots . . . .100, \$ 1.25$
CABBAGE is per $10,15 \mathrm{c} ; \ldots . . . .50,40 \mathrm{c} ; \ldots \ldots . . .100 . \quad .75$

\section{SEED CORN.}

Having raised a good crop of corn the past soason, I am able to offer a quantity of gond seed. This corn is a very large early maturing. white dent variety. It was thoroughly ripened and is as sound and heavy as anv coro I ever raised; it has been carefully aud properly handled.

PRICE per peck, 50c ........per bu. $\$ 1,50 ; \ldots \ldots . . .5$ bu. $\$ 6.25$

\section{SWEET CORN.}

Stowells Evergreen-A well known, large, late sort, productive, good quality, remains a long time in a fresh condition for use.

PRICE per pint, 20c; .quart $30 \mathrm{c}$; peck $\$ 1.00$

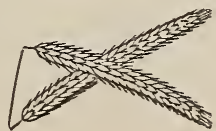

No Home is Complete without Fruit, Shade and Ornamental Trees. 


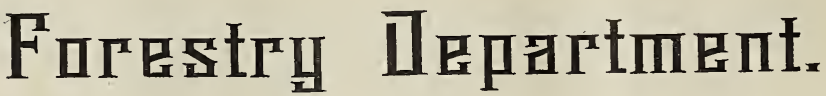

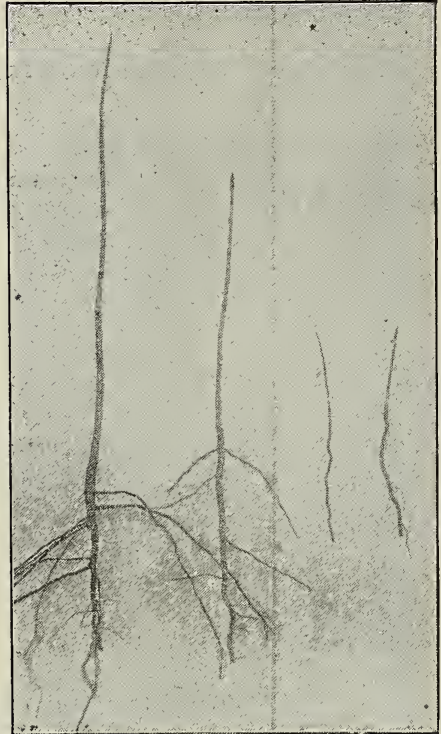

Irrigated Seedlings One year.
Non-irrigated, same age.

THE accompanying cut from a photopraph (reduced size) will give a fair idea of the comparative siza of irrigated and nonirrigated trees, the two trees on the left, the larger a Box Elder and the smaller, a Green Ash, were irrigated and ale a fair sample for siza and root supply of my 8 to 15 in grarle, and they are good enough for anvoody; the two on the right, the shme varieties, had the same soil and same care pxcept that they were not irriguted.

I niake $\rightarrow$ specialty of forest seedlings and I make the claim that my stock is as well grown and graded as any on the market anvwhere, and is not to be compared with the cheap stock commonly offered. I guarantee full count and good grades. In planting a grove do not plart all of one kind, better results are obtained with mixed plantations.

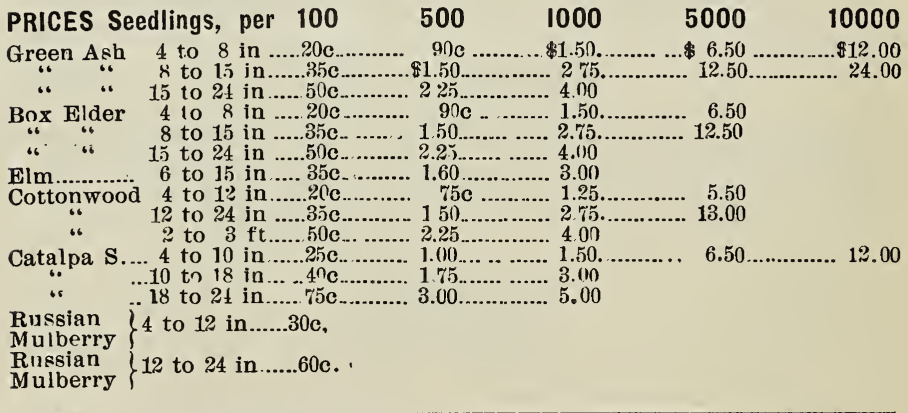




\section{CUTTINGS.}

Cuttings will be cut about 8 inches in length and tied into bundles of 100 each, with tops all one way. They can be had any length desired, if ordered a little previous to the time wanter. Keep cuttings in earth until ready to use,

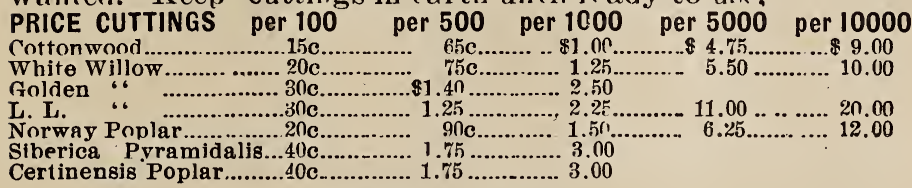

\section{TREE SEED.}

Box Elder or Green Ash per to $40 \mathrm{c}$, per 5 tos. $\$ 1.75$, per 10 ibs. $\$ 3.00$

White Elm and Soft Maple Seed lipen about last of May and should be planted soon after ripe. Get prices; order early.

The average number of a marketable seed in a nound is about as follows: Green Ash. 15,C00 ; Box Elder, 10,000 ; Soft Maple, 5,000; White Elm, 60,000.

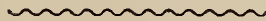 \\ Deciduous Ornamental and Shade Trees.}

Am. White Elm-A native of South Dakota, very hardy, rapid grower; endures cold and drouth well; and seldom troubled with insects, a very desirable shade or street tree.

Box Elder-A native; it sucreeds in a wide range of soils and climate; and a gond shade or street tree: gond for sugar.

Green Ash--Very hardy; a fine upright grower; suffers very little frnm ravages of insects; a very valuable tree to grow for both ornanent and timber.

Soft Maple-A native on the western streanis. perfertly hardy here after two years old. A very desirable tree, if trimmed to keep down suckers and avoid forks, which are liable to split. Its foliage is very beautiful.

Cotronwood-A rapid grower, hardy if roots reach moisture, but inclined to be short-lived on our high, dry prairies, esrecially if planted in thick groves.

Norway Poplar-Similar to cottenwond in aprearance, fully as hardy and rapid in growth; has a large and thick leaf and does not leafrust like the cottonwond. It is more storky and upright in growih and promises to be much superior to it in evers respect.

Suberica Pyramialis-A fast growing poplar, extromely hardy and rromises to do well here; 1 s equal to the Balm of Gilead for fragrance of buds and will, 1 think, prove winch more valuable.

Populus Certinensis-A Russian pollar of very rapid and upright growth. It is very desirable for the nortliwest.

Wulow, Laurel-Isaved-Russian, its fine growth and thick, glossy leaves, which glisten in the sunshine, makes it very handsome. The wond is said to be more valuable than white willow.

Willow, White-Hardy. well-known. It should be nlanted on low, wet, rich soil. Is much henefited by a heary mulch, nf litter or manure.

Willow, Golden-lts bealitiul golden-colored bark makex it desirab'e for a variety, molerately hardy with me.

My Customers are my best References, others given if Desired. 
Wild Black Cherry-Hardy, rapid grower, bears fruit abundantly when quite young. Its wood ranks next to black walnut in commercial value; very destrable for timber, rrait and ornanent.

Am. Linden---(or Basswoud)--A handsume lawn tree, grows quite rapiclly in moist soil, but quite slow in a dry one; is quite hardy here.

Black Walnuc---Valuable to grow ror nuts and tminber. It is quite hardy here, succeeds best un a rich, dee,,moist, soll, like bottom land.

Burr Oak-A native tree of spreading form, loliage deeply lobed, and the largest and inost beatiful among the oak leaves. 'Ille oakes, when they attain size, are our most picturesque trees.

Uacaipa speciusa---The liardy western variety, A symmetrical, upright, rapid grower, large, leart shaped leaf. It bears large tresses of very beautilul fragrant llowers. The timber is very durable.

Russian Mulberry---F'rom Russia. Is cultivated largely by the Russians in soutl Dakota for its fruit, which very much resembles the blackberry in appearance; liardy here.

Eu Mc. Ash-A very hainlsome lawn tree; bears clusters of red berries; quite hardy and desirable.

su. Whice Birch---1tschalky white bark and beautiful foliage make it a desirable lawn tree. Quite Lardv and rapid grower.

Hileagnus-Commonly called "Oriental Hedge." 'This is a very hardy, rapid growing, dwarfish tree, with whice silvery toliage, very striking in appearance. Its ability to endure extreme cold and urougut makes it very valuable both for ornamenting lawis and for hédges.

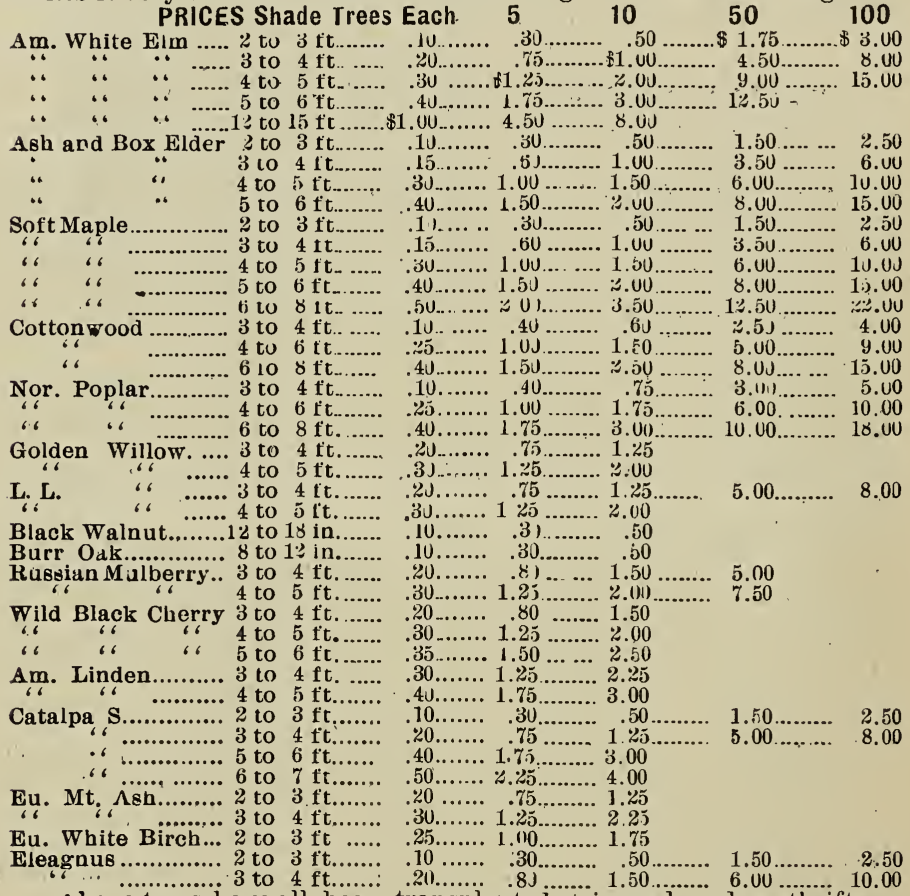

Above trees have all been transplanited, trimmed, and are thrifty.

If you don't want this Catalogue, please hand it to Some One that Does. 


\section{EVERGREENS.}

When the trees are received from the Nursery don't undo them or let the air to the roots until you are ready to wet them and place them in moist earth immediately. IN PLANTING IT IS VERY ESSENTIAL TO PACK THE EARTH VERY SOLID ABOUT THE ROOIS, and water. well if the ground is dry. Keep suriace soil perfectly mellow by cultivation, or mulch heavily with old hay; avoid bright straw, as it reflects the rays of the sum and burns the foliage.

The principal causes of failure are: First, trees are dead when received from aursery. Second, they are improperiy handled after they are receired. You must absolutely prevent drying of the roots and plunt so trees will not move around after they are planted. Large trees should be staked.

Am. Arbor Vitae--Tery b autiful for screens and hedges; has done fairly well in some parts, but cannot be said to be a complete success.

IRed Cedar-Very hardy, rapid grower when young, shears very well, indleed. It endures well our dry soil and climate; will stand more drought and hardship than any other tree; very valuable for hedges, etc.

scotch Pne-One of the hardiest, very stocky, rank and rapid grower; makes an excellent shelter belt:and while it is rather coarse and ungainly in appearance, it is nevertheless quite valuable.

w nite Pine--.Iore slender and delicate when young than Scotch, but when older it far surpasses it in growth and grace of appearance. Set-ms to do bett. $\mathrm{r}$ here than scotch but not so well farther north.

Dwarf Mr. Piue-Ad dwarf variety for planting in lawns and cemeteries; hardy and hanilsome; very bright green foliage.

Norway Spruce--Rapid, uprisht grower, valuable for screens and shelter belts; shears well and stands snow well.

White Spruce--Extremely hardy and haudsome; a very close, compact, upright grower; fi:e for ornament aud screens; holds its colur well in winter.

Col. Blue spruce--It is extremely hardy and endures the sun and drying winds;its sky-blue foliage and symmetrical form make it beautiful to behold.

These Evergreens have all been one or more times transplanted and have an abundant supply of fine fibrous roots. All home grown-will sell no other.

\section{PRICES Each per 5 per 10 per 50}

Am. Arbor Vitae 12 to 18 in .30..... $1.40 \ldots \ldots \$ 2.5 \% \ldots \ldots 10.1 .0$

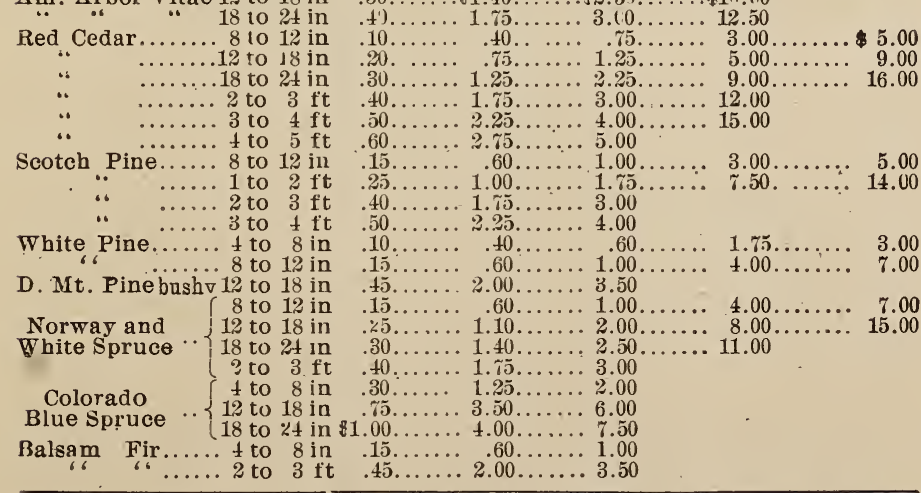

Speclal Prices made on Very Large Orders, Send List of Wants for Estimates. 


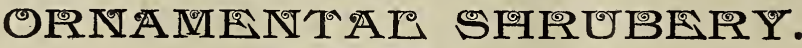

\section{FIOWERING SHIRUES.}

Common Lilac-(Purple and White, ) very hardy and well known. PRIGE each ......20c...........per $580 \mathrm{c} . . . \ldots \ldots \ldots$ ner $10 \$ 1.50$

Persian Lilac-A native of Persia, fully as hardy as the common varieties, leaf small, flowers bright purple, a profuse bloomer.

Honeysuckle-(Upright or Bush) extremely hardy and easily grown, very beautiful and desirable, either pink or white, blossoms followed by beautiful waxy red berries. State color desired.

Strawberry T'ree-A native; has handsome foliage and in Autumn has fine three cornered berries colored pink which open with the first hard freeze showing a bright crimson, which is just beneath the outer shuck or covering, very desirable and hardy .

Flowering Almond-A very hardy and good growing shrub. A small pink flower,blooms in early part of June. A very profuse bloomer.

Spirea, Van Honti-A very delicale small white blossom in clusters of ten or twelve in each bunch, is very attractive and pretty. Blooms very profusely about June 15 th, quite hardy here.

Syringa--(Single white.) A vigorous growing shrub, from 6 to 10 ft. high, blossoms profusely in June, very hardy and desirable.

Syringa-(Double.) A dwarfish shrub, flower smaller than the single, but very double and desirable, very liardy.

PRICES each .....30......... per $5 \$ 1.25 \ldots \ldots \ldots \ldots$ per $10 \$ 2.00$

\section{$\rightarrow$ CLIMBEIRS.}

Bitter Sweet---A hardy native climber, has yellow flowers in summer followed by round orange colored berries in Autumn which open similar to those of the Str. tree and about the same color.

Honeysuckle--(Trumpet) a very beautiful hardy climber with delicate trumpet shaped red flowers, blooms constantly, from early summer until hard frosts in fall; desirable.

virginia Creeper-(Am. Ivy.) One of the most vigorous and hardy climbe's, the foliage becomes a rich crimson in autumn, very desirable for walls, verandas, etc.

Clematis (Flamuli)--A very desirable climber. It is a rank grower and a very profuse bloomer, flower small green ish white.

PRInE each .....30c......... per $5 \$ 1.25 \ldots \ldots \ldots$ per $10 \leqslant 2.00$

PEONEY BU UBS-Double, very hardy and easily grown, top dies down in tall but rocts live through the winter and start again in the. spring. I have the pale rose colorea and the deep red.

PRICE Each $25 \mathrm{c} \ldots \ldots \ldots \ldots$...... per $5 \$ 1.10 \ldots \ldots \ldots \ldots$ per $10 \$ 2.00$

\section{$\Rightarrow$ ROSES.}

All roses should be laid down in the fall, and covered with dirt or coarse litter, to secure best results.

\section{JUNE ROSES.}

A frican Black-A very dark red, almost black, quite hardy.

Mundred t,eaf $-A$ delicate pink rose of rather small size and very wou? le, a narfert heanty.

Ciniamon-Hardv. strong grower, color pink, merlium in size.

Cinsh-A large and very doub'e rose: colnr a pale pink almoat white. Blonma very profucelv is a vervatrong, rank grower, and is the hardieft.

Persian Vellow-Hardy. flowers dounle and full. deep golden yel. low in color: bloome very frealy in. June The fine t hardy yellow rose grown. Strong planta each 31)c, per $5, \$ 1.40$, per $10, \$ 2.50$.

\section{CIIMBING ROSEIS.}

Queen of Prairie-A verv rank atrong grower. blooms late in Jun A bright pink of medium, size. Semi-double and hardy.

Baitimore Belle-Blush, becoming white: flowers in immense clusters, and the bud a are of fine form; falrly crvered with finwers, good climbor. hardy. PRIGES each $30 \mathrm{c} . \ldots \ldots \ldots$ per $5 \$ 1.40 \ldots \ldots \ldots$ per $10 \$ 2.50$

Always write your Name and Address Plainly to Avoid Delays and Mistakes. 
Owing to the frequent inquiries for pruning shears and knives I will endearor to keep them constantly in stock, as orily a few of the hardware stores in the country keep them.

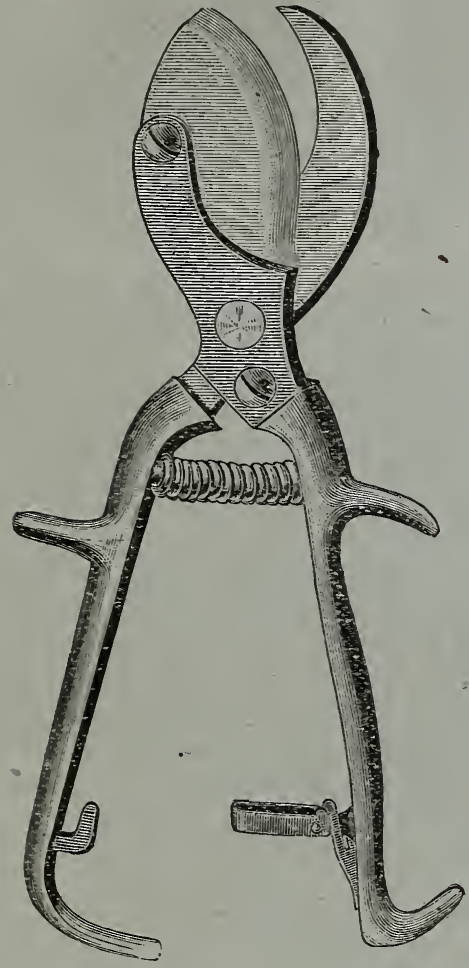

The "HENRY" Pruning Shears with malleable iron handle, blade of the best steel, coil spring, entire length $8 \frac{1}{4}$ inches, durable and well made; see cut. For pruning or making cuttings with ease and rapidity, this tool is unequalled, will cut a limb 1 inch in diameter. $75 \mathrm{c}$ each; by mail postpaid. 90c.

PRUNING KNIFE. A good strong durable knife, good strong hooked blade, made of best steel, with brown rooden handle, made to close like an ordinary pocket knife. For trimming it is enough better than an ordinary knife t) pay for itself in two days work; makes a smoother cut than the shears. 75c each; by mail, post-paid, $85 \mathrm{cts}$.

Number of Trees to the Acre at Various Distances.

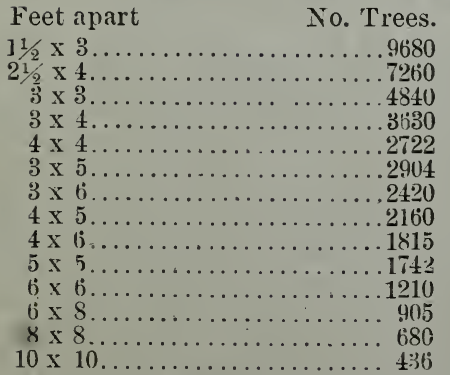

Fet apart No. Trees $10 \times 12 \ldots \ldots \ldots \ldots \ldots \ldots \ldots \ldots .363$

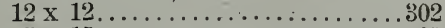

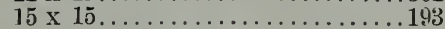
$15 \times 18 \ldots \ldots \ldots \ldots \ldots \ldots \ldots \ldots \ldots \ldots \ldots \ldots \ldots$

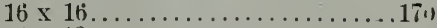

$16 \times 18 \ldots \ldots \ldots \ldots \ldots \ldots \ldots \ldots \ldots \ldots \ldots$

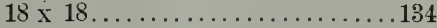

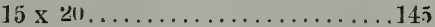

$16 \times 20 \ldots \ldots \ldots \ldots \ldots \ldots \ldots \ldots \ldots \ldots \ldots \ldots \ldots \ldots \ldots$

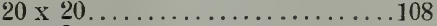

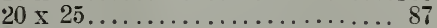

$25 \times 25 \ldots \ldots \ldots \ldots \ldots \ldots \ldots \ldots . \ldots \ldots$

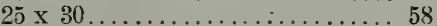

$30 \times 30 \ldots \ldots \ldots \ldots \ldots \ldots \ldots \ldots \ldots \ldots \ldots \ldots \ldots, 48$

RULE-Multiply the distance in feet between the rows by the distance the plants are apart in the rows, and the product will be the number of squire feet for each plant or hill, by which divide the number of feet in an acre $(43.560)$ and it will give the number of plants or trees to the acre. 


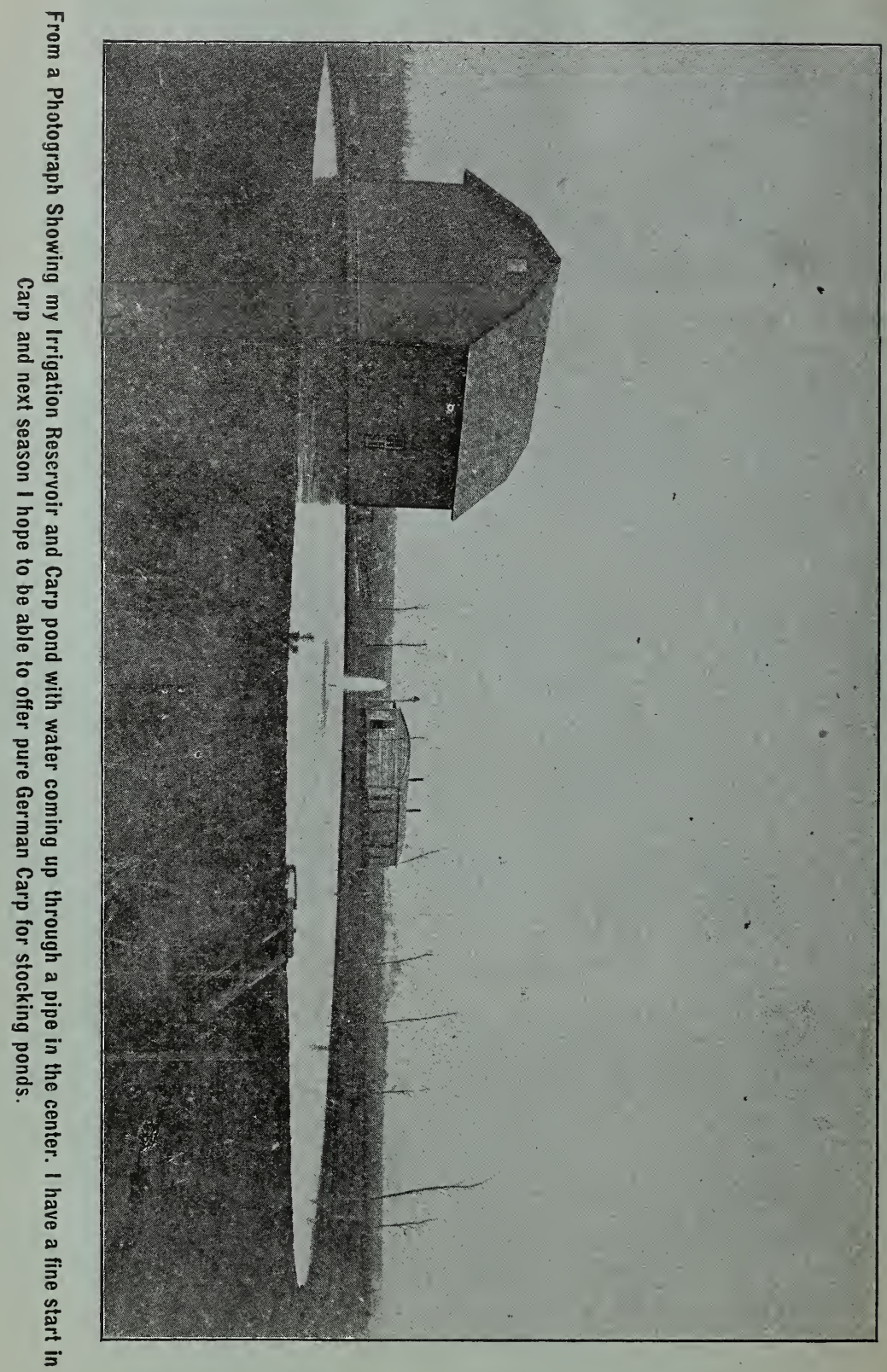

